\title{
De macht van de dood en de kracht van God: Enkele Bijbelse perspectieven
}

\begin{abstract}
Author:
Wim J.C. Weren ${ }^{1,2}$

Affiliations:

${ }^{1}$ School of Humanities,

Tilburg University, The

Netherlands

${ }^{2}$ Department of New

Testament Studies, University

of Pretoria, South Africa

Note:

Prof. Dr Wim J.C. Weren is

a research associate in the project 'Biblical Theology and Hermeneutics', directed by Prof. Dr Andries G. van

Aarde, honorary professor at the Faculty of Theology of the University of Pretoria, South Africa. This article was initially presented at the NavNUT Conference 'Mag in die Nuwe Testament', 16-19 January 2011 at the University of Stellenbosch.

\section{Correspondence to:}

Wim Weren

Email:

w.j.c.weren@uvt.nl

Postal address:

Hertog Hendriklaan 23, NL-

5062 CJ, Oisterwijk,

The Netherlands

Dates:

Received: 09 May 2011

Accepted: 16 May 2011

Published: 26 Mar. 2012

How to cite this article: Weren, W.J.C., 2012, 'De macht van de dood en de kracht van God: Enkele Bijbelse perspectieven', HTS Teologiese Studies/ Theological Studies 68(1), Art. \#1080, 8 pages. http:// dx.doi.org/10.4102/hts. v68i1.1080
\end{abstract}

C 2012. The Authors. Licensee: AOSIS OpenJournals. This work is licensed under the Creative Commons Attribution License.
The might of death and the power of God: Some biblical perspectives. This article investigates how the might of death and the power of God are related in biblical writings. Factually, there are various biblical images concerning this relationship. Four of them are discussed in this contribution. Firstly, according to many texts, there is no afterlife and God's power is limited and he is not able to save people after they have died. Secondly, view is disputed in other texts in which it is emphasised that the life of people who are faithful to God and his Torah, will have an open ending. This hope is based on God's power and not on an indestructible personal core or some divine dimension deep within human beings. Thirdly, the most well known idea is the concept of resurrection which originated in Judaism and emerged when in the second century BCE martyrs died because of their religious convictions. Fourthly, this model has been applied to Jesus, who after having been rescued from death by God, was placed in a position that in many respects is similar to God's position. In this article recent discoveries about developments in biblical ideas about God's and Jesus' competence and functions are integrated.

\section{Inleiding}

In zijn discussie met de Sadduceeën over de opstanding van de doden verwijt Jezus zijn gesprekspartners dat zij de Schriften niet kennen en geen notie hebben van de macht of de kracht van God (Mc 12:24; Mt 22:29). ${ }^{1}$ Interessant is dat kennis van de Schrift en de kennis van Gods macht over de dood hier met elkaar zijn verbonden. Dat roept enkele vragen op:

- Welk beeld geeft de Bijbel van de macht van de dood?

- Zijn de dood en God in de Bijbel twee machten die allebei heer en meester zijn over een eigen domein?

- In zijn weerwoord aan het adres van de Sadduceeën veronderstelt Jezus dat God het vermogen heeft om doden te doen herrijzen. Waarop is deze hoop gebaseerd en wat is de inhoud van deze verwachting?

- Hoe verhoudt God zich tot Jezus, en welke positie neemt Jezus in ten opzichte van God als het gaat om hun rol in de strijd tegen de dood?

In deze bijdrage start ik met een verkenning van oudtestamentische beelden van de verhouding tussen God en de dood (paragrafen 1-3). In dat verband zullen we zien dat Gods macht over de dood steeds verder is uitgebreid en langs verschillende lijnen is uitgewerkt. In paragraaf 4 bespreek ik het verschijnsel dat Jezus na zijn opwekking uit de doden door God in vroegchristelijke geloofsgemeenschappen is gaan gelden als iemand die deelt in Gods macht over de dood. Een intrigerende vraag is hoe hij zich in zijn postpaschale functie van 'leidsman ten leven' verhoudt tot 'de God van het leven' of 'de levende God'.

\section{De macht van de dood en de onmacht van God De dood vaagt mensen helemaal weg}

Dat het menselijke bestaan eindig is, is in de Bijbel een vanzelfsprekend gegeven. ${ }^{2}$ Dit wordt pas een probleem als het leven wordt ontregeld door de plotselinge en vroegtijdige dood, die de mens op een verraderlijke manier verrast en als een klapnet op hem valt (Pred 9:12). Dan wordt de overweldigende macht van de dood pas goed voelbaar.

Vele Bijbelse teksten bevatten niet de troost dat er licht gloort aan het einde van de tunnel. Nee, de dood is een zwart gat, waarin alle leven vroeg of laat verdwijnt, en er is geen weg terug (bijv. Jes 38; Ps 102; Sir 41; Pred 3:18-22; 9:4-6). In de Bijbel komen soms gelovigen aan het woord

\footnotetext{
1.Dit artikel is een verdere uitwerking van Weren (2010). In mijn weergave van Bijbelse teksten baseer ik me in deze bijdrage op de NBV Studiebijbel uit 2008. In deze uitgave van de Nieuwe Bijbelvertaling is de Godsnaam HEER vervangen door JHWH. In de Nieuwe Bijbelvertaling worden persoonlijke voornaamwoorden die naar God verwijzen, met een kleine letter geschreven. In deze bijdrage volg ik beide keuzes.
}

2.Een goed overzicht van het Bijbelse denken over de dood bieden Richards (1992), Wright (2003), Segal (2004) en Fischer (2005). 
die de dood beleven als een ernstige crisis, die de hele persoon wegvaagt. Als de dood eenmaal is ingetreden, kan ook God geen soelaas meer bieden (Ps 6:6; 30:10; 115:17-18; Sir 17:27-28). Doodgaan betekent afgesneden worden, niet alleen van de dan nog levende mensen maar ook van de levende God (Ps 88:6; Ez 37:11; zie Olyan 2003:43-51).

Vanwege zijn macht wordt de dood voorgesteld als een persoon (bijv. Jes 5:14; Jer 9:20; Hos 13:14; Job 18:13-14), maar in de Bijbel wordt de dood nergens expliciet als een god of godin gepresenteerd, die gelijkwaardig zou zijn aan Israëls God. In het Bijbelse dodenrijk zijn er geen goden, en ook Israëls God heeft daar niets te zoeken. Hier ligt een belangrijk verschil met andere Oud-oosterse culturen en religies, die de heerschappij over het dodenrijk in handen leggen van goden en godinnen.

Ook al is de dood in de Bijbel niet ook zelf een god (we zouden hier kunnen spreken van ontmythologisering), toch neemt hij een eigen positie in, naast God, en beschikt hij over een machtsgebied dat zelfs voor God niet toegankelijk lijkt te zijn. Zo komt in Psalm 88 naar voren dat er grenzen zijn aan Gods reddend vermogen. Hij kan wel iemand redden vóór de dood, maar iemand die definitief beland is in de gevangenis van het dodenrijk, kan daaruit ook door God niet meer worden bevrijd. ${ }^{3}$

\section{Wereldbeeld: De dood aan de rand en toch midden in het leven}

Binnen het Oud-oosterse wereldbeeld heeft de dood een eigen domein, het dodenrijk, dat in het Hebreeuws wordt aangeduid als de Sjeool (שאול). ${ }^{4}$ Dit domein wordt voorgesteld als een holte die onder de aarde is gelegen of op de bodem van de oeroceaan (Jes 14:15; Job 26:5; 38:16-18; Jona 2:4-7). Binnen deze visie is de Sjeool de tegenpool van de hemel, de woonstee van God, die boven de hoogste wateren troont (Ps 103:19), maar ook van Gods huis op de Sion, de tempel van Jeruzalem.

Het dodenrijk wordt soms ook gesitueerd aan het uiteinde van de aardschijf, waar de zon ter kimme neigt (bijv. Ps $42-43 ; 61: 2-3 ; 63: 1-3 ; 107: 4-7)$. In het centrum van de aarde ligt het woongebied van de mensen, dat door steppen en woestijnen, die dor en doods zijn, is afgegrensd van het domein van de dood.

In beide visies is de Sjeool een afgebakende ruimte die op grote afstand staat van de wereld van God en van de mensen. Zo is er een flinke distantie tussen de 'God van het leven' en de doden, die als onrein worden beschouwd. Na hun

3.Dat God volgens Psalm 88 geen toegang zou hebben tot de doden en geen macht zou hebben over het dodenrijk, wordt betwist door E. Noordt (2001:7-16) en Crüsemann (2003:356): 'Die Fragen im Zentrum von Psalm 88 reden von so etwas wie Auferstehung'; ibid.: '... die späteren Vorstellungen [liegen] ansatzweise schon in Psalm 88 vor, als Möglichkeiten Gottes.

4. Het woord שאול komt qua vorm overeen met de infinitivus constructus van het werkwoord wis. dat 'vragen' of 'een verzoek doen' betekent, mar wie wat vraagt aan wie is darme no niet opgehelderd. Diverse opties worden be gewogen door Jarick (1999:22-32). Zie ook Walton (2006: 313-329) en Liess gewogen door (2009:397-422).
.

5.De aanduiding 'God van het leven' (אלהים חיים) is te vinden in Deuteronomium 5:26; 1 Samuël 17:26,36; Jeremia 10:10; 23:36. overlijden gaan mensen niet naar de door God bewoonde hemelen maar naar een ruimte onder de aarde of aan het uiteinde van de wereld, waar zij worden vastgehouden als in een gevangenis, achter gesloten deuren, en waar zij geleidelijk aan verzinken in de vergetelheid.

Hoewel het dodenrijk binnen de toenmalige kosmologie een afgeschermde ruimte is, doet de macht van de dood zich niet alleen gelden in dat begrensde domein. De dood is een dynamische kracht die zich op allerlei manieren manifesteert in het leven van mensen, lang vóór hun levenseinde. Zijn macht strekt zich uit tot in het Diesseits, waar de dood zijn grimmig gezicht reeds laat zien wanneer mensen ziek zijn, getroffen worden door rampspoed, eenzaam zijn of straatarm of omringd zijn door vijanden. Het dodenrijk is overal waar de dood zijn heerschappij uitoefent. Of in de woorden van een oude Latijnse antifoon: media vita in morte sumus. Dit motief treffen we aan in diverse psalmen (bijv. Ps 22:15; $31: 13 ; 42: 2 ; 107: 18)$ en kan zowel slaan op doodservaringen van individuen als op crisissituaties waarin het voortbestaan van de totale gemeenschap op het spel staat (Jes 38:10; Jona $2: 7 ; \operatorname{Sir} 51: 6){ }^{6}$

\section{Conclusie}

Ik rond deze paragraaf af met de conclusie dat de Bijbel ruimte heeft voor het idee dat er met de dood een einde komt aan alle relaties, zelfs aan de relatie met God. Ook deze voorstelling is een geloofs- en denkmodel, en niet een pure weergave van empirische feiten. In zijn meest krasse vorm houdt dit model in dat God niet bij machte is om de macht van de dood te breken. Dood hoort bij een wereld waarin God afwezig is. Dit model is binnen de Schrift niet een relict uit een grijs verleden. Het komt ook voor in jongere geschriften, zoals Job en Prediker.

In onze westerse cultuur is dit model nog springlevend. Hoewel ons wereldbeeld totaal anders is dan dat van het Oude Nabije Oosten, kennen we nog altijd dezelfde plaats toe aan de dood. Aan de ene kant proberen we de dood zover mogelijk voor ons uit te schuiven, naar de rand van het leven. Dankzij de ontwikkelingen in de medische wetenschappen slagen we daar bijzonder goed in. De gemiddelde levensduur ligt momenteel veel hoger dan in Bijbelse tijden. Maar evengoed als toen steekt de dood nog altijd de kop op midden in het leven. Deze ervaring leidt gemakkelijk tot de vraag hoe de veel te vroege dood te rijmen valt met Gods menslievendheid. Deze vraag hoeft niet per se te leiden tot de radicale bewering dat er geen God zou zijn, maar wel zijn tijden van leegte en gemis voor gelovigen vaak tijden van Gottesfinsternis. Ook in hun leven zijn er lange periodes waarin God zich verbergt.

\section{De kracht van Gods liefde en trouw Vertrouwen op Gods trouw}

Op basis van ervaringen met Gods liefde en trouw is al vroeg een meer hoopgevend geloofs- en denkmodel ontwikkeld

6.Deze dynamische opvatting van de macht van het dodenrijk is op een treffende wijze beschreven door Barth (1947). 
dat een perspectief openhoudt op een leven dat verder reikt dan de dood, zonder dat dit perspectief wordt uitgedrukt in termen van het later opgebloeide opstandingsgeloof. ${ }^{7}$ De kern van dit model is dat God zijn relatie met mensen die zich aan hem gehecht hebben en zich houden aan de Thora, nooit opgeeft. De dood moge dan een onverbiddelijke grens zijn voor alle stervelingen, voor God is de grens waarop mensen stoten, helemaal geen grens. Hij is een bron van duurzaam leven voor allen die op hem vertrouwen en trouw zijn aan de Thora (Ps 36:6.10).

Dat een wetsgetrouw leven toekomst heeft, spruit niet voort uit een blind vertrouwen op de eigen menselijke kracht maar is geworteld in het vertrouwen dat God zijn relatie met zo iemand nooit opgeeft. Dit staat kernachtig uitgedrukt in Psalm 73:26: 'Al bezwijkt mijn hart en vergaat mijn lichaam, de rots van mijn bestaan, al wat ik heb is God, nu en altijd.' Omdat God er is, ligt de weg naar 'het leven' ook na de dood nog altijd open, zonder dat duidelijk is wat dat leven precies zal inhouden. Het bijzondere van dit model is dat de hoop op duurzaam leven gefundeerd wordt in God. Het fundament ligt in een bepaalde theologie. In de mens zelf is er niets dat de dood kan overleven, geen ziel, geen hoger bewustzijn, geen diepste Zelf. Dat zijn concepten die een ander mensbeeld veronderstellen dan het mensbeeld dat in de Bijbel centraal staat.

\section{'Leven' in Psalm 16}

Ik illustreer het hier bedoelde taalspel aan de hand van Psalm 16. Deze psalm komt uit een milieu waarin aanhangers van JHWH zich omgeven weten door vereerders van andere goden. Het lied ligt in de mond van iemand die zich misschien pas kort geleden tot Israëls God heeft bekeerd. Hij beweert dat dienaars van andere goden veel verdriet te wachten staat en dat zij al tijdens hun leven voortdurend ten prooi vallen aan de smarten van het dodenrijk. Daar staat tegenover dat aanhangers van de ENE kunnen rekenen op een veilig en gelukkig leven. De psalmist brengt dit in de verzen 10-11 als volgt onder woorden:

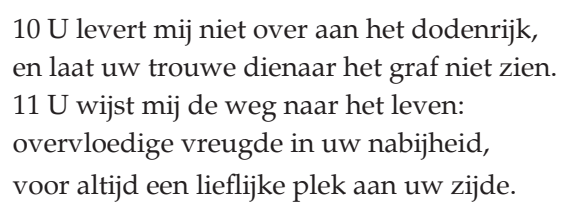

Het begrip 'leven' wordt hier gekenmerkt door een zekere semantische onbepaaldheid. Vandaar ook dat er in beginsel twee interpretatiemogelijkheden zijn. De eerste is dat de psalmist doelt op een lang en gelukkig leven aan deze zijde van het graf, een leven dat niet voortijdig wordt aangetast door kwade machten. Deze diesseitige interpretatie is te vinden in vele exegetische studies, die de hoop op een leven voor altijd aan Gods zijde hooguit kunnen zien als een tussenstap in de richting van het later ontwikkelde opstandingsgeloof (zie Liess 2004).

7.Dit wordt volkomen genegeerd door Martin-Archard (1992:680): "When one reads the OT, one fact is striking: that Israel is attached to life - to this life - and in no way dreams of a marvellous life hereafter.'
De tweede interpretatie gaat een stap verder. Een hechte verbondenheid met God en trouw aan de Thora brengen levenslang geluk en vreugde, maar daarmee is het begrip 'leven' niet uitgeput. In Psalm 16:11 is dat duidelijk omdat daar sprake is van 'overvloedige vreugde' en van geluk 'voor altijd', dat ten deel valt aan trouwe dienaren Gods, die God altijd voor ogen houden en zich ophouden aan zijn zijde (16:7). Ze koesteren de hoop dat hun leven niet onherroepelijk stukloopt op de biologische dood.

Beide interpretaties steunen op goede argumenten, maar gezien de semantische openheid van de gebezigde termen geef ik aan de tweede optie de voorkeur. Maar wellicht is het nog beter om af te zien van een nadere semantische bepaling van het door God geschonken leven. Wat dat leven inhoudt, blijft in vele teksten vaag, onbepaald en open (Deut 30:19-20; Lev 18:5; Ps 119:1, 77, 93, 159; Ez 18:9 ,17, 19, 21-22, 29; Am 5:4; Spr 3:1-2, 13-18; 4:20-22; Sir 17:11; 45:5). Daarom moeten we 'leven' hier niet inperken tot de concrete zegeningen van gezondheid, voorspoed, een gelukkig huwelijk of een rijke kinderschaar, maar evenmin moeten we de onbepaaldheid oplossen door 'leven' hier op te vatten als eeuwig en onsterfelijk leven.

\section{De groeiende competentie van JHWH}

De gedachte dat het leven een open einde heeft, is opgekomen in kringen van aanhangers van JHWH die propageerden dat hun God de enige God was die er echt toe deed. Naast hem zagen zij geen ruimte voor andere goden en machten. De functies en competenties van deze andere goden werden door hen overgeheveld naar Israëls God. Dit leidde ertoe dat hij zeggenschap kreeg over steeds meer levensterreinen.

De Duitse exegeten Gönke Eberhardt en Bernd Janowski spreken met het oog op dit proces van de Kompetenzausweitung van JHWH, waarmee de geleidelijke verbreding is bedoeld van JHWH's functies en van zijn vermogen tot handelen (Eberhardt 2007, 2009; Janowski 2009). Het door hen beschreven proces wordt bevestigd door resultaten van recent onderzoek op het terrein van Israëls religiegeschiedenis (Van der Toorn 1995; Mettinger 1995; Dietrich \& Klopfenstein 1994; Armstrong 1995; Oeming \& Schmid 2003).

Teksten uit de Hebreeuwse Bijbel wekken de indruk dat het geloof dat JHWH de enige God is, al teruggaat tot de tijd van Mozes, maar op grond van archeologische vondsten en nieuwe inzichten in de geschiedenis van Israël en van de religies en culturen van het Oude Nabije Oosten heeft in brede kring de overtuiging postgevat dat monolatrie (het vereren van slechts één God) en monotheïsme (er is maar één God die er werkelijk toe doet; andere goden hebben geen effectieve macht) in Israël pas tussen 800 en 600 ingang hebben gevonden.

Oorspronkelijk was JHWH een lokale godheid met macht over bepaalde natuurverschijnselen. In de koninkrijken Israël en Juda is hij uitgegroeid tot de nationale god, aan wie een gemeenschapsstichtende werking werd toegeschreven 
en die zijn kracht behalve in de natuur ook toonde in de geschiedenis. De ondergang van de dynastie van David en de Babylonische ballingschap (586-539 BCE) zorgden voor een diepe crisis. Israël moest zijn eigen identiteit opnieuw gaan definiëren als volk te midden van de volkeren, en in dat kader moesten ook nieuwe beelden van JHWH ontwikkeld worden. Er ontstonden twee stromingen, (1) een vernauwende stroming die het anders-zijn van Israëls cultuur en religie zoveel mogelijk wilde handhaven en JHWH graag bleef zien als een particuliere God en (2) een verbredende stroming die een grote openheid aan de dag legde voor andere volkeren en in dat verband een meer universalistisch godsbeeld ontwikkelde, waarbinnen JHWH gezien werd als heerser over alle volkeren en als schepper van hemel en aarde.

Door de geleidelijke uitbreiding van JHWH's functies kreeg hij steeds meer macht over de dood en het dodenrijk. In hun publicaties noemen Eberhardt en Janowski diverse teksten waaraan het proces van Kompetenzausweitung kan worden afgelezen. Zij plaatsen deze teksten op een tijdslijn die ongeveer 600 jaren omvat. Eberhardt maakt daarbij een onderscheid tussen het niveau van de kosmologie en dat van de soteriologie: ${ }^{8}$

Op het niveau van de kosmologie maken de in dit schema opgenomen teksten duidelijk dat het dodenrijk voor JHWH toegankelijk is, net zoals de hemel dat altijd al was. Op het niveau van de soteriologie komt naar voren dat Israëls God redding kan brengen uit de dood en dat zowel leven als dood in zijn hand liggen.

De ontgoddelijking van andere goden en de overdracht van hun competenties op JHWH culmineerden in de belijdenis dat JHWH de ene en enige God is van Israël (Deut 6:4; vgl. Ex 20:2-6; Deut 5:6-10). In dit monotheïstisch godsbeeld ligt geïmpliceerd dat God de potentie heeft om de macht van de dood in te tomen.

\section{Conclusie}

In deze paragraaf is een Bijbels taalspel beschreven waarin over een doortocht door de dood kan worden gesproken zonder dat daarvoor het jargon nodig is dat kenmerkend is voor het latere verrijzenisgeloof. In dit taalspel verschijnt God als een nabije God, die zijn getrouwen beschermt, ook in het uur van hun dood. Dit model drijft niet op het geloof van de gelovigen in God maar op Gods trouw aan gelovigen. In dit model heeft het leven een open einde, zonder dat dit concreet wordt ingekleurd.

8.Dit overzicht staat in Eberhardt (2007:401 en 2009:392). Uitgebreidere varianten daarvan zijn te vinden bij Janowski (2009:450,469) en Leuenberger (2009:171).

\section{Verrijzenisgeloof en Gods scheppingskracht}

\section{Historische context}

In deze derde paragraaf sta ik stil bij het verrijzenisgeloof, dat is opgebloeid in Joodse kringen. Verrijzen is een gelaagd begrip, dat onder meer kan slaan op de wederopbloei van Israël als natie na een diepe crisis, het herstel van een ernstige ziekte, de bevrijding uit sociaal isolement, of op het doen herleven van doden. ${ }^{9}$ De laatstgenoemde betekenis is pas opgekomen in het tweede kwart van de tweede eeuw voor het begin van onze jaartelling. Wat was dat voor een periode?

In het jaar 198 BCE hebben de Seleuciden (Syrië) de macht over Palestina overgenomen van de Ptolemeeën (Egypte). Aanvankelijk liet het nieuwe bewind de tempelcultus in Jeruzalem en de Joodse wetten ongemoeid, maar met het aantreden in 175 BCE van de Seleucidische koning Antiochus IV werd de koers verlegd. Hij wilde een verregaande hellenisering doorvoeren van de Joodse religie en cultuur. Daarbij kon hij rekenen op de steun van Joden en Jodinnen die hun geloof goed verenigbaar achtten met het Griekse denken en een Griekse levensstijl. Maar andere Joden en Jodinnen waren preciezer in de leer en meenden dat hellenistische ideeën en praktijken in strijd waren met hun trouw aan JHWH en aan de Joodse leefregels. In hun verzet tegen Antiochus en zijn Joodse supporters gingen zij zover dat ze zich liever lieten doodmartelen dan dat ze zouden willen breken met de Thora.

Het traditionele deuteronomistische retributieschema leed in deze nieuwe omstandigheden schipbreuk. Dit schema staat beschreven in Deuteronomium 28: degenen die Gods geboden naleven, worden rijkelijk gezegend met voorspoed en geluk (28:1-14), maar degenen die dat niet doen, worden getroffen door allerlei vormen van rampspoed (28:15-68). Onder het bewind van Antiochus IV gebeurde precies het tegenovergestelde. Vrome en deugdzame Joden en Jodinnen vonden de dood omdat ze zich aan de Thora hielden, terwijl het afzweren van de Thora leidde tot een comfortabel leven. In deze penibele situatie moest een nieuw denk- en geloofsmodel worden geschapen, dat erin zou voorzien dat God zijn trouwe martelaren ook na hun dood nog zou kunnen redden, en dat hij hun recht zou kunnen verschaffen, nadat zij het slachtoffer waren geworden van gruwelijk onrecht.

\section{Uit de dood doen verrijzen}

Ik bespreek dit model aan de hand van het legendarische verhaal over een moeder en haar zeven zonen in 2

9.In zijn poging om de verschillende betekenissen te classificeren komt Charlesworth (2006:1-21) tot zestien categorieën. Nummer vijftien uit zijn lijst is 'the belief in $(2006: 1-21)$ tot zestien categorieën. Nummer vijftien uit zijn lijst is 'the belief in
the resurrection of the person, in the body [...], at some future day [...], with some continuity between the person who lived, died, and was raised again by God [...], to everlasting life' (Charlesworth 2006:12).

TABEL 1: Tijdslijn.

\begin{tabular}{|c|c|c|c|c|c|c|}
\hline Jaartelling & 800-700 BCE & $700-600$ & $600-500$ & $500-400$ & $400-300$ & $300-200$ \\
\hline Kosmologie & - & Spr 15:11 & Am 9:2-4a & Job $14: 13-17 ; 38: 17$ & Ps $139: 8$ & Job $25: 5-6$ \\
\hline Soteriologie & $\begin{array}{l}\text { Individuele psalmen; } \\
\text { Hos } 6: 10-3 ; 13: 14\end{array}$ & $\begin{array}{l}\text { Individuele psalmen; } \\
\text { Ps 68:20-21 }\end{array}$ & Individuele psalmen & $\begin{array}{l}1 \text { Sam 2:6; } \\
2 \text { Kon 5:7 }\end{array}$ & Deut 32:39 & Job 33-37 \\
\hline
\end{tabular}


Makkabeeën 7. In dit verhaal worden verschillende termen gebruikt om dit nieuwe geloof tot uitdrukking te brengen: 'God zal zich over ons ontfermen' (7:6, 33); hij zal de geloofshelden 'tot een nieuw, eeuwig leven opwekken' (7:9, 14); de martelaren zullen hun afgehakte handen eens van God terugkrijgen (7:10); volgens de moeder zal de schepper van de wereld, die aan haar kinderen de levensadem heeft geschonken, de levensadem ook weer aan hen teruggeven $(7: 22-23)^{10}$; aan de broers is 'na een kortstondig lijden het eeuwige leven ten deel gevallen' (7:36).

Deze uitspraken bevestigen de actieve rol van God. De martelaren kunnen niet uit zichzelf ontwaken uit de slaap van de dood. Alleen God kan hen na hun dood nog redden. Hij doet dat niet door hen terug te laten keren naar hun oude leven van vóór de dood, maar door aan hen een nieuw leven te schenken. Daarbij wordt geen wissel getrokken op het voortbestaan van een onsterfelijke ziel. Het verhaal schenkt wel veel aandacht aan het lichaam. Omdat de geloofshelden zware fysieke verminkingen moeten ondergaan, wordt hun opwekking uit de dood voorgesteld als het herstel van hun hele persoon, inclusief hun geschonden lichaam. Met dat lichaam hebben ze gestalte gegeven aan hun religieuze en culturele identiteit. Het is dus geen wonder dat ook het lichaam moet delen in het toekomstige herstel.

\section{Verrijzenisgeloof en scheppingsgeloof}

Het idee dat martelaren na hun dood door God ten leven worden gewekt, wordt in 2 Makkabeeën 7 verankerd in het geloof dat God de schepper van de wereld is. De moeder van de zeven jongens noemt hem zo in 7:23. Zij zegt dat God aan de oorsprong staat van het ontstaan van de mens en dat hij van alles het ontstaan heeft uitgedacht. Deze bewering sluit aan bij Genesis $1-2 .{ }^{11}$ De vrouw redeneert op basis van een dubbele analogie: ${ }^{12}$

- Als God in staat was om kinderen te laten ontstaan in haar schoot en hen de levensadem heeft geschonken (vergelijk Gen 2:7), dan kan hij hen ook herscheppen door hen de levensadem terug te geven, nadat die bij hun dood naar God is teruggekeerd.

- Als God in staat was om heel de kosmos te scheppen, dan kan hij ook doden ten leven wekken. Of hierbij verondersteld wordt dat de kosmos uit het niets is geschapen (creatio ex nihilo) en dat God doden uit het niets kan doen herrijzen, is niet zeker. Een andere mogelijkheid is dat God gezien zijn ordenend handelen als schepper ook

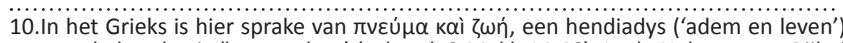
met de betekenis 'levensadem' (vgl. ook 2 Makk 14:46). In de Hebreeuwse Bijbe kunnen verschillende termen de levensadem aanduiden: ררח en נשש , Geen van deze woorden moet met 'ziel' worden vertaald.

11.Daarnaast hanteert de vrouw in 7:22-23 en in 7:27-29 technische termen uit de Griekse filosofie. Zie Weren (2010:127-130). In 4 Makkabeeën 8-17 wordt het verhaal over de zeven broers en hun moeder opnieuw verteld, maar nu in de taal van de Griekse filosofie; de toekomstige opwekking uit de dood word Nickelsburg (1992:684).

12. Hierop wees mijn collega J.W. van Henten (UvA) tijdens de conferentie 'Macht in het Nieuwe Testament' in Stellenbosch van 17-19 januari 2011, naar aanleiding van mijn voordracht over 'De macht van de dood en de kracht van God: Enkele Bijbelse perspectieven'. in staat moet worden geacht om orde te scheppen in de chaos van de dood.

Het doen herleven van doden is hier een daad van God, naar analogie van zijn scheppend vermogen. De door de vrouw ontwikkelde argumentatie gaat uit van een godsidee dat pas tijdens of kort na de Babylonische ballingschap tot ontwikkeling is gekomen. In deze kritieke periode rees de vraag of JHWH ook present is buiten het land Israël en buiten de tempel van Jeruzalem. De voormalige staatsgod, de schepper van Israël, groeide toen uit tot een God, die zeggenschap heeft over heel de kosmos en alle volkeren. De universele schepper-God kan doden laten herrijzen, door hen te herscheppen uit stof en as.

Omdat JHWH als 'de koning van de wereld' (2 Makk 7:9) een unieke en absolute positie inneemt, en omdat hij de enige is en er naast hem geen andere god is, is het ook alleen JHWH die laat sterven en leven geeft (Deut 36:39). In het verhaal over de moeder en haar zeven zonen komt naar voren dat hij individuen en groepen niet alleen kan redden uit de dood maar dat hij hen ook in het verderf kan storten, bij wijze van straf. Dat hij daartoe het vermogen heeft, blijkt uit de dreigende bewoordingen waarmee de geloofshelden zich vlak voor hun dood tot koning Antiochus richten (7:14, 17, 19, 31, 36). Deze dreigementen worden bewaarheid in het verhaal over het smartelijke levenseinde van Antiochus in 2 Makkabeeën 9. Als niet ook de macht om te doden in Gods hand zou liggen, zou er een tegenmacht nodig zijn die de dood kan brengen, maar een dergelijk duaal stelsel zou strijdig zijn met het steeds verder gaande streven naar een monotheïstisch godsbeeld.

\section{Conclusies}

Ik sluit deze paragraaf af met drie conclusies; (1) het idee dat Israëls God het vermogen heeft om doden te doen herrijzen, kwam voor het eerst naar voren in martelaarsverhalen (zoals 2 Makk 7) en in apocalyptische teksten (zoals Dan 12:1-3) die laten zien dat God aan geloofsgetuigen na hun dood nog recht kan en zal verschaffen; (2) Gods vermogen om doden te doen herleven, hangt samen met het idee dat hij er in zijn rol als schepper continu voor waakt dat de kosmos niet terugvalt in de chaos; (3) verrijzenis is een gebeuren dat aanvankelijk niet met het voortbestaan van een geest of ziel werd geassocieerd, maar betrekking had op heel de mens, inclusief zijn lichamelijkheid.

\section{Gods blijvende band met de gekruisigde Jezus}

In de paragrafen 2 en $3 \mathrm{kwam}$ aan de orde dat God zijn relatie met rechtvaardigen en martelaren nooit opgeeft. In bepaalde Joodse kringen werd hun voortbestaan uitgedrukt in termen van opwekken, opstaan of verrijzen. De achterliggende gedachte is dat het God is die de doden doet herleven. Daarvoor is niet nodig dat er in de mens zelf een onverwoestbare kern schuilgaat. Het verrijzenisidee steunt 
enkel op Gods blijvende relatie met zijn getrouwen en op zijn scheppingskracht.

\section{Jezus is door God ten leven gewekt}

Ik trek deze lijn nu door naar het Nieuwe Testament. Opvallend is hoe eenstemmig de nieuwtestamentische geschriften naar voren brengen dat de gekruisigde Jezus vrijwel meteen of in ieder geval kort na zijn dood ('op de derde dag') door God tot leven is gewekt.

Dit gebeuren wordt in het Grieks in de regel zo geformuleerd dat duidelijk is dat Jezus niet uit eigen kracht is verrezen of uit zijn graf is opgestaan, maar dat het God was die hem tot leven heeft gewekt. De plaatsen in het Nieuwe Testament

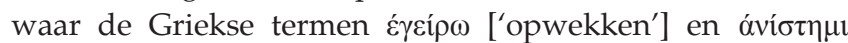
['opstaan'] betrekking hebben op het tot leven wekken of gaan herleven van Jezus, kunnen worden ingedeeld in drie categorieën: ${ }^{13}$

1. God is het actief handelend subject van het werkwoord 'opwekken' of 'opstaan': hij wekt Jezus op (bijv. Hand 3:15; in totaal 18 keer in het NT) of hij doet Jezus opstaan (bijv. Hand 2:24; in totaal 6 keer in het NT).

2. Er zijn ook teksten waarin passieve vormen van 'opwekken' worden gebruikt en het impliciet blijft wie het subject is dat de handeling voltrekt; meestal wordt verondersteld dat de handeling ook hier door God wordt voltrokken (exegeten spreken van een passivum divinum): Jezus wordt/is opgewekt (bijv. Mt 16:21; in totaal 31 keer in het NT).

3. Jezus is zelf het actief handelend subject: Jezus laat de tempel herrijzen (Joh 2:19,20; 'deze tempel' is hijzelf; zie 2:21) of Jezus staat op (bijv. Mc 8:31; in totaal 12 keer in het NT).

In de categorieën 1 en 2 is er expliciet of impliciet sprake van dat God degene is die de gekruisigde Jezus tot leven wekt; alleen de teksten uit categorie 3 gaan ervan uit dat Jezus de kracht heeft om zelf uit de dood op te staan.

De omslag na Jezus' dood wordt niet alleen beschreven in termen van opwekken of opstaan. Daarnaast zijn er nog diverse andere formules, zoals moge blijken uit het nu volgende overzicht, dat niet uitputtend is (Geysels 1996:26).

- God heeft hem hoog verheven (Hand 2:33; 5:31; Fil 2:9).

- God heeft hem verheerlijkt (Hand 3:13).

- God heeft hem een plaats gegeven aan zijn rechterhand (Ef 1:20; vgl. ook Hand 2:33; 5:31).

- God heeft hem tot Heer en Messias aangesteld (Hand 2:36).

- Hij is aangewezen als Zoon van God (Rom 1:4).

- God heeft hem de naam geschonken die elke naam te boven gaat (Fil 2:9).

- Hij is opgenomen in heerlijkheid (1 Tim 3:16).

Deze formules bevestigen of veronderstellen dat God

13.Met deze indeling neem ik afstand van de bewering van 0 . Hofius (2002:105-106)

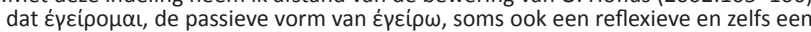
actieve betekenis kan hebben en dan weergegeven zou kunnen worden met 'hij is verrezen'. Een pleidooi voor een meer genuanceerde contextuele analyse is te is verrezen'. Een pleidooi voor een meer genuanceerde contextuele analyse is te
vinden in O'Donnell (1999:136-163). Mijn indeling van de relevante passages in drie categorieën is een variant van zijn overzicht op pagina 160. na Jezus' kruisdood een fundamentele omslag tot stand heeft gebracht. Wat deze omslag inhoudt, wordt te mager uitgedrukt als we ons beperken tot de uitspraak dat Jezus voortleeft in de herinnering, of dat de blijvende betekenis van zijn way of life door God is beaamd, of dat de zaak waarvoor hij stond door zijn volgelingen wordt voortgezet. De genoemde formules drukken uit dat er ook iets moet zijn gebeurd met Jezus zélf. Dat gebeuren kan als volgt worden omschreven: door toedoen van God heeft Jezus in eigen persoon deel gekregen aan een leven dat niet meer door de dood begrensd wordt, hij is voorgoed geborgen bij God, en vanuit deze positie blijft hij actief betrokken bij het wel en wee van zijn aanhangers.

Waarop steunt het geloof dat Jezus weer leeft? Dit geloof is het product van een complex samenspel tussen drie factoren: (1) herinneringen aan Jezus' publieke optreden; (2) nieuwe ervaringen van zijn blijvende presentie bij de zijnen na zijn dood; (3) deze herinneringen en nieuwe ervaringen zijn geïnterpreteerd in het licht van Schriftteksten. Ik geef dit samenspel eerst weer in een schema, om het daarna in het kort toe te lichten (zie Figuur 1).

In mijn toelichting begin ik met Jezus' leven. Een van de zekerste historische feiten is dat hij vol was van God en zijn Geest. Bij alles wat hij zei en deed, liet hij zich leiden door God, met wie hij een eigen, unieke relatie onderhield. Hij kondigde aan dat Gods rijk van vrede en gerechtigheid nabij was en al gestalte kreeg wanneer hij zieken genas en demonen uitdreef (Mt 12:28; Luc 11:20). Hij gaf een soms eigenzinnige interpretatie van de Thora vanuit centrale waarden zoals recht, barmhartigheid en trouw (Mt 23:23). Door de Thora in praktijk te brengen heiligde hij Gods naam. Hij zag God als een God van levenden, die trouw blijft aan zijn verbondsrelatie met individuen en groepen (Mc 12:27 parr.). Vlak voor zijn dood sprak hij het vertrouwen uit dat hij eens zou delen in de zegeningen die zouden voortvloeien uit de definitieve vestiging van Gods koninkrijk (Mc 14:25 parr.).

Zijn leven was zozeer door God getekend dat het voor de hand lag dat gezagsvolle Schriftteksten over rechtvaardigen en martelaren die na hun dood door God gered en gerehabiliteerd werden, ook op hem werden toegepast. De uiteenlopende formules waarmee Gods reactie op zijn kruisdood in het Nieuwe Testament wordt omschreven, hebben bijna allemaal hun wortels in oudtestamentische teksten. We zouden zelfs kunnen zeggen dat alle geloofs- en

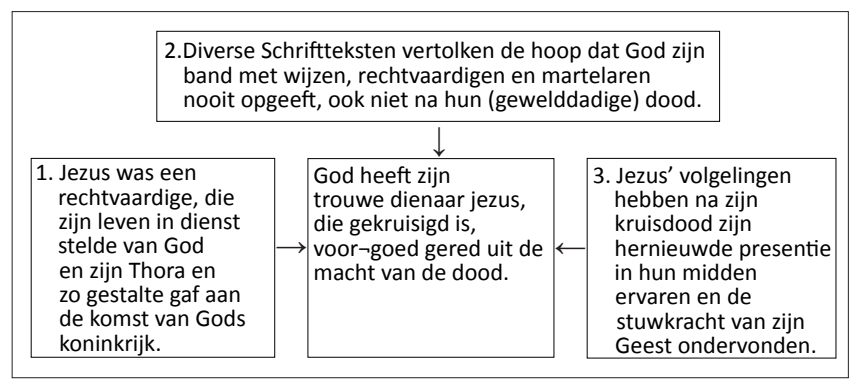

FIGUUR 1: Paasgeloof als product van drie factoren. 
denkmodellen die ik in de paragrafen 1-3 heb beschreven, in hem zijn uitgemond. Het duidelijkste geldt dat voor het derde model. Zoals het bloed van de martelaren verzoening bracht tussen God en zijn volk (2 Makk 7:33, 37), zo had ook Jezus' bloed een verzoenende werking. Door zijn dood nam hij de zonden weg van de wereld (bijv. Joh 1:29).

Het inzicht dat Jezus nu 'de levende' is, is dus de vrucht van exegese van de Schrift. Zijn lijden en dood moeten begrepen worden in het licht van Mozes, de Profeten en de Psalmen (Luc 24:27, 44). Het vermogen daartoe is niet de vrucht van een geleidelijk en moeizaam leerproces dat de leerlingen op eigen kracht hebben doorgemaakt. Naar hun vaste overtuiging was het Jezus zelf die na zijn dood hun ogen en hun verstand opende en hen tot het inzicht bracht dat hij weer leeft. Deze overtuiging werd versterkt door nieuwe en verrassende ontwikkelingen in hun eigen kring, die zij beleefden als blijken van Jezus' hernieuwde presentie in hun midden. Een constante is dat zij de nieuwe existentie van Jezus uitdrukten in relationele termen (hij is weer present in hun midden, hij werkt actief op hen in) en dat zij door deze ervaringen ook zelf tot een nieuw leven kwamen. Sanders (1993:276-281) neemt het ontstaan van vitale religieuze gemeenschappen kort na Jezus' dood op in zijn lijst van feiten uit Jezus' leven die hij historisch betrouwbaar acht. Naar zijn oordeel is het een onloochenbaar historisch feit dat Jezus' leerlingen na zijn dood bijzondere ervaringen hebben opgedaan waaruit zij afleidden dat hij door God tot leven was gewekt.

\section{Verbreding van Jezus' competentie}

Uit mijn analyse van Bijbelse beelden van Gods relatie met doden is gebleken dat JHWH steeds meer het centrum is geworden van Israëls geloof en dat zijn gezag op den duur zelfs werd uitgebreid tot alle volkeren. Tijdens dit proces werden vermogens en functies van andere goden op JHWH overgedragen, zodat hij kon uitgroeien tot de Ene en de Enige.

In de vroeg-christelijke geloofsgemeenschappen zien we een soortgelijk proces tot ontwikkeling komen. Door zijn volgelingen werd Jezus steeds meer in het centrum geplaatst van hún geloof en leven, en hij kreeg competenties en functies toebedeeld die voorheen in JHWH waren samengebald. Het proces van de overdracht van competenties van de vele goden op de ene JHWH werd nu gevolgd door het verschijnsel dat Jezus ging delen in functies die aan de Ene waren voorbehouden. Strikt genomen ging het hierbij niet om een overdracht van functies van God naar Jezus, want dan zou Jezus op den duur de plaats van God hebben ingenomen, maar om een participatie van Jezus aan Gods heilbrengend handelen.

Ik verduidelijk dit proces aan de hand van enkele voorbeelden. Het meest in het oog springende verschijnsel is dat Jezus een aantal titels krijgt die ook voor God worden gebruikt. Hiertoe behoren de naam 'Heer', die boven alle namen is, maar ook aanduidingen als koning, krijger, herder, en rechter van levenden en doden. Interessant is dat de uitspraak 'ik ben de eerste en de laatste' in het Oude Testament enkel in de mond van God ligt (Jes 41:4; 44:6; 48:12) maar in het laatste bijbelboek op Jezus wordt betrokken (Apoc 1:17; 2:8, 13). God is de alfa en de omega (Apoc 1:8; 21:6), maar Christus is dat ook (Apoc 22:13). Zoals God op den duur toegang heeft verworven tot de Sjeool, zo heeft Jezus de sleutels in handen van de dood en het dodenrijk (Apoc 1:18). 'De levende God' wordt geflankeerd door Jezus als 'de Levende' (Luc 24:5; Apoc 1:18). Zoals God aan een gestorvene de levensadem kan teruggeven (1 Kon 17:22), zo kan ook Jezus dat doen (Luc 8:55). Volgens Jesaja 25:8 zal God de dood vernietigen; in 1 Korinthiërs 15:26, 54-58 wordt deze actie aan Jezus toegeschreven.

Dit proces van de uitbreiding van Jezus' vermogens en functies leidt ertoe dat ook aan hemzelf het vermogen wordt toegeschreven om uit de dood op te staan. In het Griekse Nieuwe Testament treffen we daar al voorbeelden van aan (zie de derde categorie in mijn overzicht aan het begin van deze paragraaf). In de Vulgata is hun aantal flink uitgebreid.

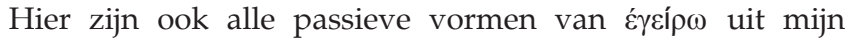
tweede categorie opgevat als activiteiten die Jezus zelf heeft voltrokken; de Griekse passiva zijn in deze Latijnse vertaling weergegeven met actieve vormen van de werkwoorden surgere en resurgere met Jezus als handelend subject. Deze zelfde Latijnse werkwoorden worden in de Vulgata gebruikt wanneer in de derde categorie in het Grieks sprake is van 'opstaan'. We zien hier dus dat de omslag na Jezus' dood steeds meer werd beschouwd als een handeling die Jezus zelf heeft voltrokken en dat zijn vermogen om dit te doen steeds sterker beklemtoond is.

Dat hij zelf de kracht heeft om te herleven en dat het initiatief daartoe bij hemzelf ligt, wordt in heel eigen bewoordingen vertolkt in Johannes 10:17-18:

De Vader heeft mij lief omdat ik mijn leven geef, om het ook weer terug te nemen. Niemand neemt mijn leven, ik geef het zelf. Ik ben vrij om het te geven en om het weer terug te nemen - dat is de opdracht die ik van mijn Vader heb gekregen.

Deze formulering past bij de overtuiging van de vierde evangelist dat de Vader en de Zoon hetzelfde doen, kunnen en willen. Toch is van een totale versmelting geen sprake, want ook in dit evangelie blijft God de bron van de kracht of de macht waarmee Jezus is begiftigd $(5: 19,27 ; 17: 2)$.

Er is dus een grens aan de uitbreiding van Jezus' vermogens en functies. Zijn positie wordt in het Nieuwe Testament niet zo ver uitvergroot dat hij een tweede God zou worden, laat staan dat hij de enige God zou zijn. ${ }^{14}$ Op het einde der tijden draagt hij zijn heerschappij over aan de Vader, die dan alles in alles zal zijn (1 Kor 15:28).

Hoe kunnen we het nieuwtestamentische beeld van de verhouding tussen Jezus en God het beste omschrijven? Een treffende beeld is dat hij 'het beeld is van de onzichtbare 14. Dit geldt ook voor de acht nieuwtestamentische teksten waarin Jezus 'God' wordt genoemd: Johannes 1:1, 18; 20:28; Romeinen 9:5; Titus 2:13; Hebreeën 1:8-9; 2

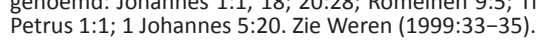


God' (Kol 1:15; 2 Kor 4:4). Daarmee is niet bedoeld dat Jezus slechts een vage afspiegeling zou zijn van God, nee, hij stelt God juist ten volle present. In Jezus als icoon van de onzichtbare God wordt zichtbaar hoe menslievend God is, dat hij recht en gerechtigheid brengt, dat hij vol mededogen is en vol zorg en dat hij iedereen vervult met de creatieve energie van zijn Geest. Jezus, die door de kracht van God tot leven is gewekt (2 Kor 13:4), is zelf Gods kracht geworden (1 Kor 1:24). Voor volgelingen van Jezus geldt dan ook dat zij niet over God kunnen spreken zonder over Jezus te spreken, maar ook het omgekeerde is waar: over Jezus spreken is voor hen ook over God spreken.

\section{Jezus' blijvende band met zijn volgelingen}

Dat Jezus uit de dood is opgewekt, houdt een hoopvol perspectief in voor zijn volgelingen: ook zij zullen de dood bij de voleinding van de wereld te boven komen. Zoals Jezus' opwekking uit de dood steunt op zijn innige band met God, zo steunt de verwachting dat ook zijn volgelingen zullen verrijzen, op hun relatie met Jezus. Hij is de eerste van de doden die zou opstaan (Hand 26:23), de gids en voorman op de weg naar het leven (Joh 14:6; Hand 3:15), de eerstgeborene onder zijn broeders (Rom 8:29), de eerstgeborene van heel de schepping (Kol 1:15), de eerstgeborene uit de doden (Kol 1:18; Apoc 1:5), de eersteling van hen die ontslapen zijn (1 Kor 15:20). De toekomst die voor de gelovigen in het verschiet ligt, wordt beschreven met relationele termen: zij zullen 'met Christus' zijn of 'in Christus' zijn (bijv. Fil 1:23; 1 Thess 4:17; 5:10), ze zullen intrekken bij de Heer (2 Kor 5:8) of met hem zijn in het paradijs (Luc 23:43).

\section{Ter afsluiting}

In dit artikel heb ik laten zien dat Bijbelse visies op leven en dood steeds verbonden zijn met voorstellingen van God en zijn macht over leven en dood. Een centrale stelling in mijn artikel is dat geloof in God in de Schrift de enige grond is voor de hoop op een leven dat verder reikt dan de dood. Deze hoop berust niet op een voor de dood onaantastbare kern in de mens zelf. Zonder de God van Israël en zijn werkzaamheid in Jezus zou de dood tot god worden. God is niet alleen de schenker van het leven; ook de dood gaat niet buiten hem om. Dat God macht heeft over de dood, is ook voor gelovigen niet altijd evident. Het is geen sinecure om in tijden van duisternis en gemis Gods presentie te ontdekken en om zich juist ook dan over te geven in de handen van iemand van wie geloofd en gehoopt mag worden dat in hem vervolmaking en voltooiing gevonden kunnen worden.

\section{Tegenstrijdige belangen}

De auteur verklaart geen financiële of persoonlijke belangen te hebben die hem ongepast kunnen hebben beïnvloed bij het schrijven van dit artikel.

\section{Literatuurverwijzingen}

Armstrong, K., 1995, Een geschiedenis van God: Vierduizend jaar jodendom, christendom en islam, Anthos, Baarn.
Barth, C., 1947, Die Errettung vom Tode in den individuellen Klage- und Dankliedern des Alten Testamentes, Evangelischer Verlag, Zollikon.

Charlesworth, J.H., 2006, 'Where does the concept of resurrection appear and how do we know that?', in J.H. Charlesworth et al. (eds.), Resurrection: The origin and future of a biblical doctrine, pp. 1-21, T \& T Clark, New York, NY/London.

Crüsemann, F., 2003, ,Rhetorische Fragen? Eine Aufkündigung des Konsenses über Psalm 88:11-13 und seine Bedeutung für das alttestamentliche Reden von Gott und Tod', Biblical Interpretation 11, 345-360.

Dietrich, W. \& Klopfenstein, M.A. (Hrsg.), 1994, Ein Gott allein? JHWH-verehrung und biblischer Monotheismus im Kontext der israelitischen und altorientalischen Religionsgeschichte, Universitätsverlag, Freiburg Schweiz. (OBO, 139).

Eberhardt, G., 2007, JHWH und die Unterwelt: Spuren einer Kompetenzausweitung JHWHs im Alten Testament, Mohr Siebeck, Tübingen. (FAT, 2. Reihe, 23)

Eberhardt, G., 2009, ,Die Gottesferne der Unterwelt in der JHWH-Religion', in A. Berlejung \& B. Janowski (Hrsg.), Tod und Jenseits im alten Israel und in seiner Umwelt: Theologische, religionsgeschichtliche, archäologische und ikonographische Aspekte, pp. 373-395, Mohr Siebeck, Tübingen.

Fischer, A.A., 2005, Tod und Jenseits im Alten Orient und Alten Testament, Neukirchener Verlag, Neukirchen-Vluyn.

Geysels, L., 1996, Tot leven gewekt: Verrijzenisgeloof bijbels beleden, Lannoo, Tielt.

Hofius, O., 2002, „,'Am dritten Tage auferstanden von den Toten“: Erwägungen zum

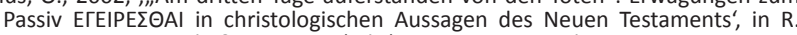
Bieringer, V. Koperski \& B. Lataire (eds.), Resurrection in the New Testament, pp. 93-106, University Press/Peeters, Leuven. (BETL, 165).

Janowski, B., 2009, JHWH und die Toten: Zur Geschichte des Todes im Alten Israel", in A. Berlejung \& B. Janowski (Hrsg.), Tod und Jenseits im alten Israel und in seiner Umwelt: Theologische, religionsgeschichtliche, archäologische und ikonographische Aspekte, pp. 447-477, Mohr Siebeck, Tübingen.

Jarick, J., 1999, 'Questioning Sheol', in S.E. Porter, M.A. Hayes \& D. Tombs (eds.), Resurrection, pp. 22-32, Sheffield Academic Press, Sheffield. (JSNTSup, 186).

Leuenberger, M., 2009, ,Das Problem des vorzeitigen Todes in der israelitischen Religions- und Theologiegeschichte', in A. Berlejung \& B. Janowski (Hrsg.), Tod und Jenseits im alten Israel und in seiner Umwelt: Theologische, religionsgeschichtliche, archäologische und ikonographische Aspekte, pp. 151-176, Mohr Siebeck, Tübingen.

Liess, K., 2004, Der Weg des Lebens: Psalm 16 und das Lebens- und Todesverständnis der Individualpsalmen, Mohr Siebeck, Tübingen. (FAT, 2 Reihe, 5)

Liess, K., 2009, „,'Hast du die Tore der Finsternis gesehen?“ (ljob 38,17): Zur Lokalisierung des Totenreiches im Alten Testament', in A. Berlejung \& B. Janowski (Hrsg.), Tod und Jenseits im alten Israel und in seiner Umwelt: Theologische, religionsgeschichtliche, archäologische und ikonographische Aspekte, pp. 397-422, Mohr Siebeck, Tübingen.

Martin-Archard, R., 1992, s.v. 'Resurrection (OT)', The Anchor Bible Dictionary 5, 680-684.

Mettinger, T.N.D., 1995, s.v. 'Yahweh Zebaoth', in K. van der Toorn, B. Becking \& P.W. van der Horst (eds.), Dictionary of deities and demons in the Bible, col. 1730-1740, Brill, Leiden/New York, NY/Köln.

Nickelsburg, G.W.E., 1992, s.v. 'Resurrection (Early Judaism and Christianity)', The Anchor Bible Dictionary 5, 684-691.

Noordt, E., 2001, ,Tod und Zukunft: Das Wagnis des Ezechiel: Ez 37,1-14 und die eschatologische Hoffnung', in E. Noort \& M. Popovic (Hrsg.), Hoffnung für die Zukunft: Modelle eschatologischen und apokalyptischen Denkens, pp. 7-16, Universiteitsdrukkerij Rijksuniversiteit Groningen, Groningen.

O'Donnell, M.B., 1999, 'Some New Testament words for resurrection and the company they keep', in S.E. Porter, M.A. Hayes \& D. Tombs (eds.), Resurrection, pp. 136-163, Sheffield Academic Press, Sheffield. (JSNTSup, 186).

Oeming, M. \& Schmid, K. (eds.) 2003, Der eine Gott und die Götter: Polytheismus und Monotheismus im antiken Israel, Theologischer Verlag, Zürich. (AThANT, 82)

Olyan, S.M. 2003, "“We are utterly cutt off": Some possible nuances of ngzrnw Inw in Ezek 37:11', Catholic Biblical Quarterly 65, 43-51.

Richards, K.H., 1992, s.v. 'Death: Old Testament', The Anchor Bible Dictionary 2, 108-110.

Sanders, J.P., 1993, The historical figure of Jesus, Allen Lane The Penguin Press, London.

Segal, A.F., 2004, Life after death: A history of the afterlife in the religions of the West, Doubleday, New York.

Van der Toorn, K., 1995, s.v. 'Yahweh', in K. van der Toorn, B. Becking \& P.W. van der Horst (eds.), Dictionary of deities and demons in the Bible, col. 1711-1730, Brill, Leiden/ New York/Köln

Walton, J.H., 2006, Ancient Near Eastern thought and the Old Testament: Introducing the conceptual world of the Hebrew Bible, Baker Academic, Grand Rapids, MI.

Weren, W., 1999, 'Vier vensters op Jezus, de Zoon van God', in W. Weren, H. Kuitert \& N. Schreurs, Jezus: Zoon van God?, pp. 24-38, Meinema, Zoetermeer.

Weren, W., 2010, Dood, en dan? Stemmen uit de Bijbel, echo's in onze cultuur, Meinema, Zoetermeer, Pelckmans, Kapellen.

Wright, N.T., 2003, The resurrection of the Son of God, Fortress, Minneapolis, MN (Christian origins and the question of God, 3). 